\title{
Exploration on Transformation and Innovation of College Library Service in Digital Age
}

\author{
Wei Luo \\ Zhuhai College of Jilin University \\ Zhuhai, China
}

\begin{abstract}
College library is the center of literature information in colleges and important pillar to colleges to carry out teaching and scientific research. This article starts with challenges faced by college library in digital age, briefly analyzes the existing problems and discusses that readers get information and change reading mode, puts forward to improve comprehensive quality of librarian, integrate resources in the library, exploit scope of services, change service mode, complete service transformation of college library in digital age, promote service quality and serve as the bridge and link for spread of literature resources.
\end{abstract}

Keywords-college library; reader service; transformation; innovation

\section{INTRODUCTION}

Shayla, an American master of library science says, "Service is the basic aim of library". Cheng Yanan, a research librarian, also thinks in New Discussion on Library Service, "Service is the main line of library development in the 21st century and the core value of library". As college library under digital environment, it is no longer simple reader services such as borrowing, returning as well as searching of books. With continuous development and change of type of literature information and continuous development of digital information, readers' requirements for information also change enormously. It requires the contents of information resources to become more professional and advanced. It demands to carry out continuous and deeper excavation, development and use of contents in information. It will inevitably cause transformation of library service for readers and trigger thinking and innovation of service method and service mode.

It is more necessary for college libraries to continuously innovate in and explore service, improve comprehensive quality, service quality and service level of librarians and change from basic service of teaching and scientific research to active, advanced and original service pattern, serve readers inside school. Meanwhile, it shall increase communication with the outside world, give consideration to socialized services and serve as the link of various information communication and services.

\section{Digital Age MaKes College Library FACE NEW Challenges}

\section{A. Information Environment Brings Great Changes and Recombination of Literature Information Resources}

In 2014, the 11th national reading survey report once pointed out, "In 2013, the contact rate of digital reading mode of grown-ups in our country increases continuously. Among them, online reading, reading by mobile phone and reading by e-book reader increase to some extent". The information service platform becomes diversified. Readers' dependency on library especially paper resources decreases. It requires college libraries to rethink and reposition construction and integration of literature resources and conform to the requirements of readers in digital age.

Compared with paper books, electronic documentary resources have advantages, especially high timeliness, no geographic restrictions as well as simple and rapid transmittal mode. But it also has deficiencies such as disordered resources and low authority. Therefore, it is necessary to process, clear up, renovate and extract these resources and then provide readers with effective, integral and safe literature information resources.

\section{B. Service Objects Need Expansion and Adjustment}

With dramatic development of social economy and cause of cultural education in our country, the service object of college library must be expanded to some extent. On the basis of serving teaching and scientific research of this school, it shall open to face the community then society as soon as possible, serve development requirements of cultural undertakings of the whole country, conform to inevitable development tendency of modern library and adapt to diversified and personalized requirements of users.

\section{Service Means and Ways Need Changes and Innovation}

Service object of traditional college library has boundedness. So means and ways of service are also relatively single. The service mode is passive, sticks to convention and waits for readers to come actively. According to the survey and visiting, it is found that now most of college libraries have the phenomenon that the amount of borrowing of paper books decreases. Because of continuous development of digitalization, readers have a great diversity of ways and 
terminals to acquire information resources. They no longer simply rely on library. Therefore, college libraries no longer have the upper hand on information resources. It requires college libraries to expand service object and broaden service ways as well as innovate in service means. It can not wait readers to come actively but take the initiative to provide timely, accurate and advanced literature information resources.

\section{Diversified and Convenient Terminals and Platforms of Document Information Retrieval Bring Great Impact for College Libraries}

The rapid development of electronics technology produces various forms of terminals such as laptop, mobile phone and ipad. Through these terminals, readers can acquire information resources required by themselves without restriction of region and time. It will be not the first choice of readers to borrow paper documents from the library.

\section{E. Diversity of Information Platform Compels College Libraries to Have Characteristic Service}

Make the best of favorite ways of young readers to promote the communication with readers, especially platforms such as WeChat and microblog that readers pay high attention to, in order to push information, complete the interaction with readers and arouse interest of readers.

\section{COUNTERMEASURES FOR TRANSFORMATION AND INNOVATION OF LIBRARY SERVICE IN COLLEGES}

\section{A. People First, Attach Great Importance to Talent Cultivation and Improve Comprehensive Quality and Cultural Literacy of Librarians}

In December 31st, 2015, article 11 of the latest Regulations for Higher Learning Institution Libraries issued by Ministry of Education of our country put forward the following requirements for librarians: For librarians, including professional librarians and assistant librarians, the quantity of professional librarians shall be no lower than 50 percent of total number of librarians. Professional librarians shall have master's degree or above level or senior title of a technical post and receive professional education or systematic training of library science. Assistant librarians shall have college degree of higher education or above level.

No matter face the society or colleges, the service object is people, who also provide services. Therefore, if college libraries want to carry out transformation and innovation of reader service, the first breakthrough point is also people. The principal part that provides services is composed of staff in library. Therefore, improving comprehensive quality and cultural literacy of librarians is one of the primary tasks to promote transformation and innovation of library service in colleges.

1) Improve ability of librarian of screening, identification and integration of knowledge: As college libraries, one of the contents of basic service is to provide retrieval service of literature information for teaching and scientific research. Librarians need to organize, analyze, extract and clear up information resources collected then provide them for readers to use. Librarians in colleges under digital age must change into navigator and leader of knowledge.

2) Improve ability of librarians to communicate with foreign languages: In colleges, there are increasing numbers of activities that communicate with all sectors of society and overseas students in foreign university. In library of Zhuhai College in Jilin University, there are overseas students. When receiving these readers, it requires librarians to have the ability to communicate with simple oral English, know requirements of these readers and provide good service.

The retrieval of literature information includes Chinese document resources and many foreign advanced information resources. Many thesis and resources are original editions written in English. Without certain English level, it is impossible for librarians to provide accurate and efficient information resources for readers that have this kind of requirement or departments of teaching and scientific research.

3) It is necessary for librarians to have certain capacity to operate computer: Digitalization brings revolution of machine. The lending ways of library also change from traditional manual mode to network and computer modes. Librarians shall expertly master computer technologies such as library management system, office software, maintenance and use of database. It is the basic requirement for librarians to integrate into information system.

4) Librarians need to strengthen learning and improvement of professional level and comprehensive qualities: Varied disciplines do not exist independently but have intimate connections and cover each other. Librarians in college library need to know about development trend of teaching and scientific research in schools and thoroughly understand professional knowledge. Meanwhile, they shall also cursorily read information resources of non-professional fields and provide accurate and reliable comprehensive guide. Therefore, it requires colleges to support librarians to participate in professional training and external exchanges, broaden the horizon.

5) They shall have certain knowledge on psychology, first aid and ability to deal with emergencies: As public place with dense population, college library serves readers as well as undertakes the responsibility to serve and educate people, protect security of readers and public property. It is necessary to find emotional fluctuation of readers, coordinate with student work department to carry out psychological guidance, timely find, and guide and eliminate abnormal emotion of readers to reduce the risk. Proper first aid knowledge and ability to deal with emergencies such as fire disaster buy time to deal with all kinds of emergencies and rescues.

B. Implement Ideological Building of Librarians in College Library and Give Full Play to Leading Function of Service of Grass-Roots Service-oriented Party Organization in College Libraries and Form Incentive Mechanism

Regularly carry out activities of appraisal through comparison and communication with the outside world, drive 
librarians and the masses to stimulate their potential and enthusiasm, enhance spirit of unity and cooperation and motivate consciousness of innovation and service concept.

\section{The Service Resources Shall Be Diversified}

Except for traditional paper resources, it is necessary to realize digitalization of information resources, reasonably allocate matching ratio of different types of literature information resources as well as plan and integrate, in order to meet requirements of different types of readers. Meanwhile, they shall also implement the core collection construction and pay attention to center on and guarantee key subject construction and major setup situation of the college.

Paper literature resources are principal part of collection resources in traditional libraries. It focuses on collection. It provides services for readers through ways such as lending out and reading inside the library. Electronic documentary resources in libraries in digital age increase continuously. The advantages also appear continuously. But it also has disadvantages such as insecurity and instability and cannot completely replace paper document. College libraries need to attach importance to make respective advantages of these two kinds of literatures complementary to each other and avoid resource replication. Meanwhile, they need to build scientific library collection structure system, screen and integrate electronic resources and carry out regular spot check, maintenance and backups.

\section{Carry out Mutual Literatures Borrowing Service between}

\section{Libraries with Surrounding College Libraries to} Complement Resources of Each Other on Professional Disciplines and Realize Sharing and Complementation of Resources

As library of independent college, it can build sharing relationship of electronic resources through strengthening connection and cooperation with maternal university. Taking Zhuhai College of Jilin University as an example, it can realize resource sharing with Jilin University through ways of substituted retrieval and query. Disciplines in Jilin University cover a broad range. Database resources of Chinese and foreign languages are complete and rich. It saves cost and covers the shortage of information resources within appropriate time.

\section{E. Change Service Concept, Innovate in Range of Services, Enlarge the Scope of Services and Walk out of School Gate of Colleges and Integrate with the Society}

College libraries in digital age shall not rigidly adhere to reader service inside school. The service object shall expand from colleges to community and society and respond to requirements of development of national cultural undertakings.

At present, the library in Zhuhai College of Jilin University has carried out some social service items. Especially carry out service of literature information with surrounding enterprise and public institutions, coordinate with district government to carry out community construction projects such as "Happy Village" and actively participate in and drive cultural construction of community.

\section{F. Realize Individualization of Reader Service, Make the Service Mode Change from Passive to Active and Develop from Simple to Deep Level}

Go deep into and deepen from basic borrowing and returning of books, reference service and discipline service to follow-up service, reader communication and customized service, orient and position according to different requirements of teaching, scientific and major, integrate and track the latest relevant information resources and provide advanced and accurate information service for teaching and scientific research. Designate specially-assigned person to track and understand projects and researches of cooperative enterprise and public institutions, collect and sort information to provide literature information resources required by them. Meanwhile, provide corresponding information for college through these ways and provide basis and source for cooperation with enterprise and public institutions. For example, the library in Zhuhai College of Jilin University cooperates with surrounding enterprises and public institutions such as district cultural center and has provided service for enterprises and public institutions continuously for many years. Besides, it cooperates with them to carry out activities such as "Reading Festival" to enrich cultural life of community residents.

\section{G. College Libraries Shall Obey the Tendency of Service Platform from Single to Diversified Type and Closely Follow the Pace of Age}

In digital age, WeChat, microblog and QQ have become important platforms for readers of the young generation to acquire knowledge, the same as popularization of terminal cell phone, IPAD and computer. Most audiences of college library are young readers. College libraries can make the best of platforms such as WeChat to promote and popularize relevant business and information resources of library. The timeliness and popularization far surpass propaganda work of webpage and better conform to preferences and habits of readers of the young generation.

\section{H. College Libraries Can Better Attract Readers with Characteristic Information Resources and Services}

The collection and integration of information resources is a long-term and huge project, not demanding perfection but pursuing improvement and characteristics, realizing that other do not have but we have as well as we have superior quality than others. Integrate with economic development and construction direction of this region or historical and cultural development to construct data resource base with academic or regional cultural characteristics. For example, construct academic paper database of teachers and students of this school, graduation thesis library, economic and cultural research on Pearl River Delta, characteristic literature library in research on Hong Kong and Macao and Lingnan culture. Attract readers inside the school and surrounding enterprises and public institutions to establish long-term effective cooperation and provide advanced and professional information resources. 


\section{Attract Student Readers to Participate in the Work and Construction of College Library to Provide Valuable Advices and Suggestions for the Library}

College libraries aim at serving teaching and scientific research. Students are the crowd that is closest to the use of library. Letting students participate in management and service can know about requirements of readers and provide opportunities for students that have financial difficulty to carry out part-time-work and part-time-study and participate in social practice. Make librarians have connection with the changing age and know about different requirements and ideas of readers at different ages.

\section{CONCLUSION}

Under the environment of digital age, the transformation and innovation of reader service in college libraries are the inevitable trend to comply with development of social and national cultural undertakings. In this process, it is necessary to pay attention to improve comprehensive quality of librarians, continuously change and innovate in way of reader service, service ways and service platform, expand range of services, show characteristics of college libraries and improve self competitive capabilities, better embody the purpose of "readers first, service first". It shall become solid assistant and dependence of teaching and scientific research in colleges, make contributions for the development of social cultural undertakings and become new type of college library under the new age.

\section{REFERENCES}

[1] Li Jun. Information Literacy of College Teachers in the Age of Big Data [J], Theory and Practice of Contemporary Education, 2014, (9).

[2] Zhang Hui. Management Innovation of Circulation Department of College Library in Digital Age [J], Contemporary Education Sciences, 2014 (19).

[3] Yu Shehua. Application of WeChat in Library Information Service of Higher Vocational Colleges-Take Xingtai Polytechnic College as an Example [J], Journal of Xingtai Polytechnic College, 2015.10 (32-5)

[4] Shi Lihui. Discussion on Innovation of Library Service in Colleges of Our Country [J], China Electric Power Education, 2013 (34).

[5] Fu Weitang, Huang Xiongping. Current Situation and Development Strategy of Library Collection Construction in Independent Colleges of Guangdong Province $[\mathrm{J}]$, Library in Independent College and Higher Vocational College, 2011 (14).

[6] Sun Xuegang. Research on Harmonious Development of Electronic Resources and Paper Resources in Colleges-Take University of Science and Technology of China and Hefei University as Examples [J], Journal of Huaibei Vocational and Technical College, 2014.8 (13-4).

[7] He Haibo. Discussion on Transformation and Innovation Development of Library Service in Colleges [J], Journal of Changchun Normal University, 20 (34-4).

[8] Notice of Ministry of Education on Issuing Regulations for Higher Learning Institution Libraries (Revise), Jiao Gao (2002) No. 3. 